\title{
Research on Regulatory Enforcement Forces of Shaanxi Local Government Debt
}

\author{
Fuqing Yue ${ }^{1}$ \\ Xi'an International University, 710077 \\ hunter2011@foxmail.com
}

Keywords: Shaanxi; Regulatory Enforcement Forces; Local Government Debt

\begin{abstract}
Through 30 years of reform and opening up, China's undertakings have achieved rapid development. But at the same time, local governments have accumulated a lot of debt. Chinese local government debt issue has caused domestic and foreign economists and decision-makers attach great importance to it. It is an important thing to strengthen local government debt management and regulatory enforcement power to prevent and resolve the debt risk to ensure the sustainable, healthy and stable development of the Chinese economic and social. In this way, this research of Chinese local government debt management has important theoretical and practical significance.
\end{abstract}

\section{Introduction}

Chinese local government debt issue has caused domestic and international decision-makers and economists are highly valued. Early in August 2010, the Ministry of Finance, the National Development and Reform Commission, People's Bank of China and China Banking Regulatory Commission jointly deployed four departments of local government debt financing platform for the company to conduct a comprehensive clean-up work. Premier Wen Jiabao's government work report made by March 5, 2011 at the Fourth Session of the Eleventh National People's Congres noted that in 2011 local government debt will conduct a comprehensive audit, the implementation of the full oversight and control, establish standardized local government debt financing mechanism. Domestic and foreign economists have also dwell on the scale of China's local government debt, structure, risks, causes and countermeasures and other issues [1].

Strengthening local government debt management, prevent and resolve debt risk is to ensure sustained, healthy and stable development of important economic and social state of things. Chinese local government debt management has important theoretical and practical significance. Theoretical performance, the study of local government debt management and help promote the deepening and development of public finances theoretical research, but also to enrich and improve important aspects of public management theory. Practical Significance in: help control and prevent local government debt risk; to further define the relationship between the government and the market, correct and full implementation of government functions; help improve government transparency and public information and contribute to the Government's public management level.

\section{Chinese Local Government Debt}

Local government debt is short for local government debt. According to the National Audit Office's classification standards, local government debt, including local governments bear the responsibility to repay the debt, local governments bear the responsibility of the secured debt and local government may bear some responsibility for debt relief. Local governments bear the responsibility to repay the debt refers to debt repayment required by the local financial capital, is a local government debt; local governments bear the responsibility of the secured debt is secured by means of local governments, while being unable to repay a guarantor, local governments should bear joint and several liability of debt; local governments may assume responsibility for debt relief means certain local governments did not have the legal responsibility to repay, debt-servicing difficulties arise when the debtor, the local government may give some debt relief. After the two types of debt should be repaid by the debtor to its own income, under normal circumstances without 
government assume debt obligations, it is a local government liabilities. Debt can be a simple sum of the above two types, collectively referred to as local government debt.

\section{Related Theory of Local Government Debt}

The Fiscal Decentralization Theory. The first generation of fiscal decentralization theory is that local government debt is the need of fiscal decentralization. Compared with the central government, local government has the advantage of providing information on the number of places in terms of public goods, if it comes to the need to finance public goods, it will generate local government borrowing needs. In addition, the characteristics of local government borrowing or part of fiscal decentralization, and fiscal decentralization process and direction are closely related. Fiscal decentralization will also produce the reverse effect. From the perspective of institutional reform, fiscal decentralization and local borrowing system, it should be jointly advance. Further, the tax system, sub-production system, sub-system is the debt relationship between the three pillars of the government's revenues are divided, missing any one of them, property rights relations between governments are unstable [2].

Economics Theory and Sociological Theory of Intergenerational Equity. Intergenerational equity is one of the core elements for achieving sustainable development, intergenerational equity refers to the present and future generations in the use of natural resources, enjoy clean environment and seek equal rights on the survival and development. $\mathrm{T}$-Page first proposed the concept of intergenerational equity, intergenerational equity problem is pointed out that the consequences of decisions on how current among future generations for problem of equitable distribution; Professor Edith Brown Weiss first proposed the theory of intergenerational equity, intergenerational equity raised three in principle, clearly stated in intergenerational access to resources, the environment, the opportunity to the second aspect of fairness; to define, judge intergenerational equity, Yang Qin industry put forward intergenerational equity classification model, put forward a quantitative basis for the realization of intergenerational equity [3].

Ricardian Equivalence Theory. Ricardo believes that government borrowing and taxation logic is the same. The core idea is that the Ricardian equivalence theorem: bonds are not net wealth, the government either in the form of taxes, or in the form of bonds to get the public revenue, the impact of economic choices for people are the same. Expenditure either through taxation or through the issuance of bonds currently financing, there is no difference, that is nothing more than delay the tax debt, in the eyes of consumers with a completely rational, debt and taxes are equivalent.

\section{The Local Government Debt Risk of Shaanxi Province}

The Internal Debt Risk. According to Ministry of Finance statistics caliber local government debt, local government debt data includes direct debt, the secured debt and food policies of losses of three parts. The former is mainly government debt and other domestic institutions or individuals formed, while the latter is mainly a direct relationship between government debt and international financial organizations or foreign governments finance debt risk control matrix can be seen mainly formed by the contractual relationship local government debt can be seen as a direct amount explicit debt, debt guaranteed by the government formed mainly or explicit debt, food policy are direct losses are implicit debt: The above statistics because there is a more clear data sources, reliability It is relatively high, and there is the implicit debt or as local financial companies to stay bad, local pension gap, bankruptcy and liquidation of state-owned enterprises, the financial gap due to the lower levels of government uneven caliber statistics, cannot be used as a basis for analysis, Therefore, this article only in accordance with the statistical Treasury debt burden of government debt in Shaanxi Province to inspect the situation [4].

The External Debt Risk. Shaanxi Province from 1984 began to use international financial organizations and foreign government loans, has been 25 years of history. By the end of 2008, the province's total foreign investment capital has agreed to use \$ 3.08 billion, loans to projects 1023; $\$ 63,720,000$ for grant funds, grants 576 . These loans are mainly invested in water conservancy, 
transportation, education, health, agriculture, poverty alleviation, environmental protection and other fields. Judging from the loan sources, mainly the World Bank, the Asian Development Bank, IFAD and the Government 16 countries, by the statistics, at present, Shaanxi Province has entered the period of foreign loan project has reached 72, at the peak of foreign debt repayment period.

\section{The Initiatives to Improve Regulatory Enforcement Power of Local Government Debt of Shaanxi}

Clear Operational Framework of Public Finance. Through a clear division of power and financial power of governments at all levels to build between rational and standardized government transfer payment system, local governments have a steady source of income and a reasonable range of expenses, so that to avoid excessive burden on the central government in the formation of the ethical considerations, but also local government spending has sufficient financial security, although build intergovernmental fiscal relations system to guard against financial risks not only made arrangements, but an important means of financial power between the Government clear, but rigorous scientific, rational, orderly , defining the relationship between property rights and powers to match the financial risk is local institutional "firewall."[5]

Improve the Government's Debt Management System. Since the local government debt financing is a necessity, then the institutional framework of public finances by further deepening of the basic science division of government powers on property rights, the government debt into the budget management, rationally determine the local government finance and debt management Permissions, clear funding sources of financing, use, repayment way through hard budget constraint of local government borrowing norms. In addition, regardless of whether the powers given to local government borrowing, higher levels of government must strengthen the management of local government debt, strengthen the monitoring of local government debt. For now, Shaanxi Province has strong concealment in terms of non-Treasury debt in nature, such as arrears of pension, arrears of wages and other staff, which is most evident in the performance of the county poles, and mostly recessive and or Under liabilities, caused by the government's vigilance is not easy, but once the place of local government debt reached unsustainable proportions, in order to ensure social stability, the central government will have to come up with money to solve this problem, or provincial financial situation had become increasingly stretched increased financial support to the city, and thus strengthen the management of local financial debt is a priority.

Improve the Local Financial Risk Early Warning System. Strengthen risk awareness, risk monitoring situation may occur, and timely adjustment policies, avoid financial risks of local governments into fiscal crisis. Strengthen the monitoring mechanism to run local finance, establish a reasonable local financial risk early warning system, we need to select a range of visible indicators quantization control according to the actual financial operation, which helps prevent the risk of further deepening. Ohio mode although fine structure, but still has a very significant limitations: risk indicators (l) financial monitoring system used in essentially static, they do not reflect the government revenue, expenditure and debt trends, therefore, financial stability cannot be directly assessed; (2) a bigger drawback is that most of the indicators are based on traditional financial accounts of a government cash flow and direct debt, they do not merely reflect the government or within the limits of a small liabilities. Therefore, government finances will be placed under the economic operation monitoring the stable operation in the background, and a reasonable set of early warning indicators become more difficult choice.

\section{Conclusion}

The fundamental way to solve the debt problem and prevent debt risk is economic development and at the same time we need to improve the local debt monitoring and early warning systems, strengthen monitoring and supervision. Through the improvement of financial risk early warning mechanism, the development of the financial risk monitoring indicators, we can forecast and monitor for early detection and solve problems. 


\section{Acknowledgements}

Subject: 2014 year of the Shaanxi Provincial Department of education scientific research project (Project number: 14JK2114)

\section{References}

[1] J.H. Wu, Institutional Economics Analysis of Local Government Behavior in Land Acquisition Process, Rural Economy, 2005, 7.

[2] Y.F. Han, The Thinking about Local Government Economic Function and Economic Behavior, Northwest University (Philosophy and Social Sciences). 2001 (11)

[3] J.J. Li. Chinese Local Government Economic Behavior: Based on Public Choice Perspective.China Industrial Economy, 2004, (04): 27

[4] B.Y. Qiao, China Fiscal Decentralization and Compulsory Primary Education. Chinese Social Science, 2005, (6): 37-46

[5] H.L. Zhang. Fiscal Decentralization and Local Government 's Behavior. Journal of Zhongnan University of Economics. 2007( 6) 